Volume 7 Issue 2, June 2020

Nationally Accredited Journal,

Decree No. B/4130/E5/E5.2.1/2019

\title{
Juridical Analysis Of Standard Procedure Operational Management And Services (SPOPP) In Making Shari'a Notary Deed Based On Article 15 Paragraph (1) Of Law Number 2 Of 2014 Concerning The Position Of Notary
}

\author{
Mochamad Rizqi Sismanto ${ }^{1}$, Anwar Saleh Hasibuan ${ }^{2}$ and Aryani Witasari ${ }^{3}$
}

Abstract. The purpose of this study was to: 1) to analyze the implementation of standard operating procedures and service settings (SPOPP) notary in the deed of Shariah is based on article 15 paragraph (1) Law No. 2 of 2014 on the notary office. 2) to analyze the legal consequences sharia deed made by the notary pursuant to Article 15 paragraph (1) Law No. 2 of 2014 on the notary office. The data used in this study are primary data, secondary data and data that can support tertiary study, which was then analyzed by qualitative descriptive method.

Based on the analysis of data concluded that: 1) the execution of a deed notarized by a notary Shariah-based, there are two models in the inclusion of Bismillahhirrohmanirrohim writing. The first one is the inclusion of the article after the title, and the second inclusion Lafadz Bismillahhirromanirrohim/writing there were no written or written and included in the premise. 2) the legal effect of Shariah -based of authentic act by a notary depends on the placement Bissmilahhirrohmanirrohim writing. The first in the inclusion of the text at the beginning of the deed would have violated the rules of the article 38 of Law Notary, that at the beginning consists of the title deed deed, certificate number, full name and place of notary. The second in the inclusion of Bismillahhirrohmanirohim writing something was written and there are included in the premise.

Keywords: Notary, Authentic Deed, Bismillahhirrohmanirohim Writing.

\section{Introduction}

Shariah in Indonesian economy is growing and accepted by society. This is because the economic system of Shariah apply non-usurious transactions (prohibition of usury) and motivated by the events of the oil crisis in 1974 and 1979 that lead to the financial power in the form of petrodollars to countries in the Middle East region and North Africa, including Indonesia, Malaysia, and Brunei in Southeast Asia. ${ }^{4}$ Now the existence of Shariah increasingly advanced economy, in which we can see with the establishment of several of the financial institutions such as banks Shari'ah based, insurance Shariah to the hotel.

The financial institution's own Shariah differs from conventional financial institutions. One difference between the two is that the financial institutions in the financial institution Shari'ah there must be a clear Underlyng transaction, so money should not be profitable on its own without the base transactions, such as buying and selling that will cause margins, capital investments which resulted in the division results and lease which would give rise to a fee. ${ }^{5}$ So the difference between financial institutions syar'iah conventional financial institutions

\footnotetext{
${ }^{1}$ Student Master of Notary Program, Faculty of Law, Sultan Agung Islamic University Semarang, Email: mochamadrizqisismanto491@gmail.com

${ }^{2}$ Student of Master of Law Program, Faculty of Law, Universitas Islam Sultan Agung email anwarsaleh.hsb.86@gmail.com

${ }^{3}$ Lecturer of Faculty of Law, Sultan Agung Islamic University Semarang

${ }^{4}$ Lawrence Arliman S, 2016, Urgensi Notaris Syai'ah Dalam Bisnis Syariah Di Indonesia, Padang: Walisongo, p.81.

${ }^{5}$ Fathurrahman Djamil, 2012, Penerapan Hukum Perjanjian Dalam Transaksi di Lembaga Keungan Syari'ah, Jakarta: Sinar Grafika,p.v
} 
located in the transactions and contract.

Then what is meant by the contract as stated in article 1 paragraph 13 of Law Sharia banking is a written agreement between the Bank Shariah or Shariah business unit and others loading their rights and obligations of each party in accordance with the principle of Shari'ah. ${ }^{6}$ In the above explanation that the contract can be called with a decisive, because a contract can be said to have grappled with the look of the transaction on the contract, whether in accordance with the principles of Shariah or not. From this, the contract agreed between the Bank Shariah or Shariah Business Unit with the other party will be posted to a notarial deed in which are contained within the rights and obligations between the parties are in agreement and in accordance with the principles of Shariah.

Notary authority itself has been described in Article 15 Paragraph (1) UUJN, reads: ${ }^{7}$

"Notary authorized to make the deed authentic of all deeds, agreements, and determination required by legislation and / or desired by the stakeholders to be stated in the certificate is authentic, guaranteeing the creation date of the deed, saving certificates, give, copy and quotes deed, all of it along a deed that is not also assigned or excluded to other officials or any other person specified by law."

The role of the notary in the current development is needed professionalism in the running position. Demands for a notary must be a deed syariah contract basis agreed between the Bank Shariah or Shariah Business Unit with the contents the customers in the form of rights and obligations of both parties. In deed the Shariah itself certainly a new thing for most notary, which also accommodates the interests of Shariah or of religious values so that the deed itself does not rule out the possibility to be included unusual in deed. As is now still a debate among notaries and society in general, are related to the placement lafadz Bissmillahhirrohmanirrohim at the beginning of the deed after deed number, ${ }^{8}$ Thus, in a deed of Shariah, the notary must be careful in making the form and structure it ensures legal certainty.

From the above problems prompted the authors to conduct research that is manifested in a study entitled "Analysis of the Implementation of Standard Operating Procedures Juridical Regulation and Services (SPOPP) Notary Deed In Making Shariah Pursuant to Article 15 Paragraph (1) of Law No. 2 of 2014 About Notary. "

From the description of the background of the above problems, the formulation of the problem in this study, namely: How Standard Operating Procedures Implementation Regulation and Services (spopp) Notaries in deed Shari'ah based on Article 15 (1) of Law No. 2 of 2014 On Notary? How the legal consequences shari'a deed of Notary under Article 15 paragraph (1) of Law No. 2 of 2014 On Notary?

\section{Research methods}

In this study, the authors used normative juridical approach, namely a study deductively starting analysis controlling the articles in the legislation governing against the above problems. What is meant by judicial legal research is the research refers to the study of existing literature or of secondary data is used. While the law is normative research is to acquire knowledge about the relationship between a normative regulations with other regulations and application in practice.

\footnotetext{
${ }^{6}$ Article 1 of Law No. 21 of 2008 concerning Sharia Banking

${ }^{7}$ Article 15 Paragraph (1) of the Law On Notary

${ }^{8}$ Maras S 2009, lafadz Bismillah is the embodiment of God's intentions because of a servant when going to perform an act. Inclusion lafadz bismillah in the preparation of Shariah contracts, intended for the implementation of the contract has a value of worship. Burhanuddin S, Hukum Kontrak Syariah, Yogyakarta: BPFE-Yogyakarta, p.190.
} 
Volume 7 Issue 2, June 2020

Nationally Accredited Journal,

Decree No. B/4130/E5/E5.2.1/2019

\section{Results and Discussion}

\subsection{Standard Operating Procedures Implementation Regulation and Services (SPOPP) Notaries in deed Shari'ah based on Article 15 (1) of Law No. 2 of 2014 On Notary}

In the development of Shariah banking course will require an important role of a notary public. Notary described in Article 1 paragraph 1 of Law Notary is a public official who is authorized to make the authentic act and have more authority as referred to in legislation or based on other legislation. ${ }^{9}$ The authority granted by law to the notary be a demand for a notary to be professional in their profession. In achieving professionalism and protection of the services of a notary, the notary must have professional skills in the field of law should also be based on the responsibility and the moral high ground as well as in the execution of the duties of office as well as the values and ethics, thus performing his respective duties in accordance with the provisions of the law and the public interest.

An important role of a notary in the development of Shariah banking we can see, such as notary institution which has been involved in issuing legal description of the contract-business contract Shariah. ${ }^{10}$ In order for an agreement to have the force of law, it must be registered before a notary. Therefore, every business Shari'ah including the Shariah business. Keep in need of a notary as an authentic deed officials in accordance with the duties set forth in Law No. 2 of 2014 concerning Notary. ${ }^{11}$

Implementation of the notary in making authentic act must also be guided by Law Notary. The existence of the Law on Notary of great importance for the notary for in this Law, not only related to a deed contains authentic, but also contains related commands and sanctions that must be followed by a notary. ${ }^{12}$

In connection with the form or structure of the notarial deed Adjie Habib stated that the deed made before or by notary shape is defined in Article 38 of Law No. 2 of $2014 .^{13}$ Stated that every deed consists of: Early Head Deed or Deed; Deed Agency; Closing the end Deed or Deed.

As well as making authentic deeds in general, in the manufacture of Shariah-based authentic act also guided by the provisions in the Law on Notary. One of the problems faced by the notary is in the inclusion of lafadz Bismillahhirrohmanirohim that where it is not regulated more clearly in UUJN.

In the execution of the notary in making authentic act of Shariah -based possessed three models, the first one being the inclusion of the text at the head of the deed, the second inclusion Bismillahhirromanirrohim writing imprinted into the premise and the third, there is no written or written.

\subsubsection{Inclusion Posts Bismillahhirrohmanirohim Being Head of Deeds;}

In the implementation of the notary who made the authentic act in which shariabased placement Bismillahhirohmanirohim writing at the beginning of the deed, found

\footnotetext{
${ }^{9}$ Article 1 of Law No. 2 of 2014 On Notary

${ }^{10}$ Sutjipto in Ustad Fair 2011, Mengenal Notaris Syari'ah, Bandung: Citra Aditya Bakti, p. 40.

${ }^{11}$ Ustad Fair, Ibid, p, 85-86.

${ }^{12}$ According to Salim HS, 2015, that the suffix "it" means to the post of "notary", which act acts of government by legislation, ie the Law No. 2 of 2014 on the Amendment of the Act No. 30 of 2004 concerning Notary office, Salim HS., Teknik Pembuatan Akta Satu (Konsep Teoritis, Kewenangan Notaris, Bentuk dan Minuta Akta), Jakarta: Raja Grafindo Persada, p. 69

${ }^{13}$ Habib Adjie, 2013, the Civil and Administrative Sanctions Against Notary as Public Official, Sanksi Perdata dan Administratif Terhadap Notaris sebagai Pejabat Publik, Bandung: Refika Aditama, p. 49.
} 
Bismillahhirohmanirohim actual sentence, which means the Calling Name of Allah the Merciful and infinite, have translations and interpretations as an opening to educate and teach His servants to read Basmalah if you want to start a good job that needs attention. Power-effort (nature) by which man do, in which is God's gift. The people will not do anything if not blessed with God. Therefore, if a man wants to do something with nature. Then he began to invoke the name of God, the nature of the One who gave it to him. ${ }^{14}$

Bismillahhirohmanirohim lafadz their pronunciation in the field of banking Shariah authentic deed is a sign that deed made in the form of deed still refers to the provisions of Islamic law, or Shariah (Al-Quran and Hadith).

\subsubsection{Inclusion Posts Bismillahhirromanirrohim In Premise or Deed Agency;}

Indonesia is a country of law, it is stated in Article 1 paragraph (3) of the Constitution of the Republic of Indonesia of 1945. Fajar Muktistates that the concept of constitutional state is an idea that appears to defy absolutism concept which has spawned a unitary state. In essence, the ruling power should be limited in taking legal action. ${ }^{15}$

Entry manufacture authentic act in accordance with Article 38 of Law Notary is a manifestation of the principle of legality and as legal certainty for the parties execute an agreement in the banking Shariah.

In lafadz Bismillahhirrohmanirohim inclusion in the Shariah-based authentic act which placed at the beginning of the deed of an aberration that has been set in Article 38 UUJN. According Febriyanti Dwi Putri, argues in his journal that without the inclusion of lafadz Bismillahhirrohmanirohim deed in banking Shariah is as the adjustment in Law No. 2 of 2014 concerning Notary. It also reflects the principle of legality as one element in the concept of the legal state of Indonesia. ${ }^{16}$

\subsubsection{Inclusion Posts Bismillahhirromanirrohim Not Posted;}

In the inclusion of Bismillahhirromanirrohim article was not written in a deed. This is because in the rules of Act No. 2 of 2014 concerning Notary and / or Act No. 21 of 2008 concerning Sharia Banking which does not set out clear related Bismillahhirromanirrohim lafadz placement inclusion in the notary deed. Therefore, It is the same as it is with reason notary in lafadz Bismillahirrohmanirrohim inclusion in the premise that where in a deed authentic shape and composition remain in accordance with the legislation in force it reflects the principle of legality and the principle of legal certainty.

\subsection{As A Result of the Deed Law Shariah Made By Notary Pursuant to Article 15 Paragraph (1) of Law No. 2 of 2014 On Notary}

In essence, all deed made by the notary is an authentic deed. The notarial deed can not be said to be the authentic act if it does not fulfill the conditions set out in Law Notary. According to Article 1868 of the Civil Code, the authentic act is an act made in the form prescribed in the Act by or before the competent public authority for it in the certificate was made. ${ }^{17}$ Notarial deed so that it can be said if the authentic act in accordance with the provisions set out in the Act and made before or made before a competent public authority.

\footnotetext{
${ }^{14}$ Bachtiar Surin 2004, Az-Zikra (Terjemahan dan Tafsir Al-Qur'an), Bandung: Angkasa, p. 3-4

${ }^{15}$ Idul Rishan, 2013, Komisi Yudisial Suatu Upaya Mewujudkan Wibawa Peradilan, Yogyakarta: Genta Press, p. 9-10

${ }^{16}$ Febriyanti Dwi Putri, 2016, Keududukan Akta Perbankan Syari'ah yang Dibuat Oleh Notaris Menurut UU No. 2 Tahun 2014 Tentang Perubahan Atas UU No. 30 Tahun 2004 Tentang Jabatan Notaris, Palembang: Journal thesis as a requirement for obtaining a master's degree at the Universita notaries Sriwijaya, p15.

${ }^{17}$ Article 1868 Civil Code Book
} 
Volume 7 Issue 2, June 2020

Nationally Accredited Journal,

Decree No. B/4130/E5/E5.2.1/2019

In the execution of a notary deed inShariah banking there are three that have been explained above. So the inclusion of lafadz Bismillahhirohmanirohim at the beginning of the word, according to Habib Adjie in view of the principle of legality does not have legal certainty or position aktanya degraded into deed under hand. ${ }^{18}$ This is because in a deed to the provisions of the deed beginning and end of the deed of the responsibility of a notary, and the contents of the deed part is the responsibility of the parties to make sharia contract. ${ }^{19}$ So that notaries are not allowed to add or change themselves about the rules and customs that have been practiced. ${ }^{20}$

Thus the notarial deed that is not in accordance with the rules stipulated in Law No. 2 of 2014 On Notary position has been degraded into a deed under hand. This is confirmed in Article41 of Law No. 2 of 2014 which reads: "Violation of the provisions referred to in Article 38, Article 39 and Article 40 resulted in deed only has the strength of evidence as the deed under the hand." 21

Legally, under Article 1869 of the Civil Code specifies that a deed that is not treated as an authentic deed, either because it is not authorized or not in public officials concerned as well as due to a defect in shape have the power as a deed under hand when signed by the parties. Then in Article 1874 of the Civil Code is determined that the hand is considered as the text below is a deed signed under hand, letters, lists, letters household affairs and other writings made without the mediation of attacking a public official.

Thus, in the second model and a third model for inclusion lafadz Bismillahhirohmanirohim who poured on premise or not written, remains as authentic act in which a notary deed made in accordance with the rules stipulated in the Law on Notary. So that in the deed has the legal certainty and reflect the principle of legality considering Indonesia is a country of law in accordance with Article 1 (3) of the Constitution of the Republic of Indonesia of 1945 (1945).

In this case I do not mean to disagree with the opinion that lists lafadz notary Bismillahirrohmanirrohim at the beginning of the deed. But in this case I want to see from the legal viewpoint and to keep in a notarial deed. Given the notary is a public official who makes authentic act in order to ensure certainty, order and legal protection. And strengthened by the precautionary principle by a notary, that which requires the notary to always be careful in carrying out his duties, in the sense to be consistent in implementing the legislation in the field of notaries based on the professionalism and good faith. ${ }^{22}$

\section{Closing}

\subsection{Conclusion}

Based on research results be concluded as follows:

- In lafadz Bismillahhirrohmanirohim inclusion in a notarial deed in banking Shariah there are three models made by a notary. The first one is the inclusion of the article after the title, the second inclusion Bismillahhirromanirrohim posts included in the premise, and the third inclusion Bismillahhirrohmanirrohim lafadz there is not written. Of course, the

\footnotetext{
${ }^{18}$ Habib Adjie, ibid, p. 49.

${ }^{19}$ Adjie Habib and Mohammed Hafidh, 2017, Akta Notaris untuk Perbankan Syariah, Bandung: Citra Aditya Bakti, p. 68.

${ }^{20}$ Ibid., p.59.

${ }^{21}$ Article 41 of Law Notary

${ }^{22}$ Sam Dwi Zulkarnen 2008, Prinsip Kehati-Hatian Notaris Sebagai Pejabat Umum Dalam Melaksnakan

Jabatannya, Jakarta: Thesis of University of Indonesia Postgraduate Notary, p. 74.
} 
inclusion of lafadz Bismillahhirrohmanirrohim in a deed by each notary has a different opinion.

- That in the manufacture of Shariah -based notarial deed with a legal effect different. In the case of the first model is the inclusion of lafadz Bismillahhirrohmanirohim lead to degradation of the deed becomes deed under hand which is enshrined in Article 41 of Law No. 2 of 2014 On Notary. And the second model and the third model is lafadz Bismillahhirrohmanirohim inclusion set forth in the premise or not written is not a legal effect, which is where the remains in accordance with the rules of Act No. 2 of 2014 concerning Notary.

\subsection{Suggestion}

- The role of the notary in the deed authentic Shariah banking sector is very important. This is in order to ensure legal certainty associated in an agreement. So in this case there should be discussion related to infusion related lafadz Bismillahhirrohmanirohim, so that there is uniformity and unity in a deed. And certainly in the discussion related equipment also pay attention to Law No. 2 of 2014 concerning Notary and sources of Islamic law.

- The presence of a notary authority described in Article 15 of the Law Notary, one of which is to ensure legal certainty for the parties related to the running of an agreement. So that for the avoidance of degradation deed into a deed under the hand of course need unification manufacture authentic act in the field of banking Shari'ah. Unification pooling their manufacture Shariah-based notarial deed will keep the status of the deed itself and maintain the strength of evidence that has always been strong in case of problems. So as to reflect the principle of legality and the principle of legal certainty.

\section{References}

[1] Bachtiar Surin, 2004, Az-Zikra (Terjemahan dan Tafsir Al-Qur'an), Bandung: Angkasa

[2] S.Burhanuddin, 2009, Hukum Kontrak Syariah, Yogyakarta: BPFE-Yogyakarta

[3] Fathurrahman Djamil, 2012, Penerapan Hukum Perjanjian Dalam Transaksi di Lembaga Keungan Syari'ah, Jakarta: Sinar Grafika

[4] Febriyanti Dwi Putri, 2008, Keududukan Akta Perbankan Syari'ah yang Dibuat Oleh Notaris Menurut UU No. 2 Tahun 2014 Tentang Perubahan Atas UU No. 30 Tahun 2004 Tentang Jabatan Notaris, Palembang: thesis as a requirement for obtaining a master's degree at the Universitas Sriwijaya notaries

[5] Habib Adjie, 2013, Sanksi Perdata dan Administratif Terhadap Notaris sebagai Pejabat Publik, Bandung: Refika Aditama

[6] Adjie Habib and Mohammed Hafidh, 2017, Akta Notaris untuk Perbankan Syariah, Citra Aditya Bakti. Bandung.

[7] Idul Rishan, 2013, Komisi Yudisial Suatu Upaya Mewujudkan Wibawa Peradilan, Yogyakarta: Genta Press

[8] Salim HS, 2015, Teknik Pembuatan Akta Satu (Konsep Teoritis, Kewenangan Notaris, Bentuk dan Minuta Akta), Jakarta: Raja Grafindo Persada

[9] Sam Dwi Zulkarnen, 2008, Prinsip Kehati-Hatian Notaris Sebagai Pejabat Umum Dalam Melaksnakan Jabatannya, Jakarta: Thesis of Notary Master Graduate University of Indonesia

[10] Act 1945 of the Republic of Indonesia

[11] The Code of Civil Procedure

[12] Law No. 2 of 2014 concerning Notary

[13] Act No. 21 of 2008 concerning Sharia Banking 